\title{
SKIRTINGOS TEMPERATŪROS POVEIKIS KELIO TIESIAMŲJŲ IR LENKIAMŲJŲ RAUMENŲ NUOVARGIUI IR ATSIGAVIMUI
}

\author{
Irina Ramanauskienè ${ }^{1,2}$, Marius Brazaitis ${ }^{1}$, Albertas Skurvydas ${ }^{1}$, Vitas Linonis ${ }^{2}$, \\ Aleksas Stanislovaitis ${ }^{1}$, Mindaugas Dubosas ${ }^{1,2}$ \\ Lietuvos kūno kultūros akademija ${ }^{1}$, Kauno technologijos universitetas ${ }^{2}$, Kaunas, Lietuva
}

\begin{abstract}
Irina Ramanauskienè. Lietuvos kūno kultūros akademijos biomedicinos mokslų krypties doktorantė. Kauno technologijos universiteto Kūno kultūros ir sporto centro, Kūno kultūros katedros lektorė. Mokslinių tyrimų kryptis — raumenų fiziologija: šildymo ir šaldymo poveikis raumens nuovargiui bei atsigavimui priklausomai nuo lyties ir raumens susitraukimo greičio.
\end{abstract}

\section{SANTRAUKA}

Tyrimo tikslas - nustatyti, kaip skirtinga temperatūra veikia kelio tiesiamuju ir lenkiamuju raumenu jèga, nuovargi ir atsigavimq. Tiriamieji - fiziškai aktyvūs 19-23 metu vyrai $(n=10)(\bar{g} g i s-177,8 \pm 5,8 \mathrm{~cm}$; kūno masè $78,2 \pm 6,1 \mathrm{~kg}$ ). Buvo atlikti trys eksperimentai skirtingai raumenu büsenai ìvertinti. Tiriamieji testuoti „Biodex Medical System 3" - žmogaus kaulu ir raumenu testavimo ir reabilitacijos iranga, kai raumenys iprastinés temperatūros, pašildyti ir pašaldyti. Buvo atliekama: kontrolinis testavimas prieš krūvi (3 kartus tiesiant ir lenkiant koja per kelio sqnari fiksuotu 450 /s greičiu); praejjus 2 min - izokinetinis krūvis (50 kojos tiesimu ir lenkimu per kelio sqnari fiksuotu $450^{\circ}$ / s greičiu); praejjus 10, $30 \mathrm{~min}, 1 \mathrm{~h} 10 \mathrm{~min}$ ir $24 \mathrm{~h}$ po krūvio - kontrolinis testavimas pagal ta pati protokola. Laktato (La) koncentracija kraujyje buvo nustatoma prieš fizinì krūvì bei praejjus 5 ir 30 min po jo. Kreatinkinazés (CK) aktyvumas kraujo serume nustatomas prieš krūvị ir praejjus 24 h po jo.

Raumenu susitraukimo jejga esant maksimaliajam greičiui testavimo metu tiesiant koja sumažejo 80\%, lenkiant $\sim 85 \%$. Kelio tiesiamuju raumenu jëga 50-o susitraukimo metu (A 0) sumažëjo (iprastinès temperatūros tiesiamuju raumen $-18,1 \pm 14,2 \mathrm{~N} \cdot \mathrm{m}$, pašildytu - 19,9 $\pm 14,3 \mathrm{~N} \cdot \mathrm{m}$, pašaldytu - 20,8 $\pm 9,2 \mathrm{~N} \cdot \mathrm{m}$; iprastinès temperatūros lenkiamuju raumenu - 9,0 \pm 7,2 $\mathrm{N} \cdot \mathrm{m}$, pašildytu $-8,3 \pm 8,9 \mathrm{~N} \cdot \mathrm{m}$, pašaldytu $-5,8 \pm 5,2 \mathrm{~N} \cdot \mathrm{m}(p<0,05$, lyginant su kontroline reikšme).

Gauti rezultatai parodè, kad skirtinga temperatūra reikšmingai nepakeitė kelio tiesiamuju ir lenkiamuju raumenu susitraukimo jegos esant maksimaliajam greičiui. Raumenu atsparumas nuovargiui 50 kartu tiesiant ir lenkiant koja per kelio sqnari nepriklauso nuo šildymo ir šaldymo. Raumenu susitraukimo jéga esant fiksuotam $450^{\circ}$ / s greičiui atsigavo praejjus 10 min po krūvio nepriklausomai nuo temperatūros. Tiek šildymas, tiek šaldymas prieš krūvì netiesiogiai sumažino raumens pažeidos simptomu (CK) raiška praèjus 24 h po krūvio. Skirtinga raumenu temperatūra po krūvio reikšmingai nepakeitè La koncentracijos kaitos.

Raktažodžiai: izokinetinis krūvis, raumenu susitraukimo jėga esant maksimaliajam greičiui, raumenu nuovargis ir atsigavimas, raumenu šildymas, šaldymas.

\section{IVADAS}

S varbus žmogaus motorinès sistemos funkcinis požymis yra jos gebejjimas prisitaikyti prie îvairių aplinkos dirgiklių. Motorinès sistemos galimybès gali labai kisti, ypač morfologinès ir funkcinès (Enoka, 1994). Dauguma fiziologiniu ir kitų organizme vykstančių procesu yra glaudžiai susiję su kūno temperatūros pokyčiais (Bennett, 1990). C. J. de Ruiter ir A. de Haan (2000) nustatè, kad temperatūra veikia aktino ir miozino miofilamentų funkcija, todèl raumenų darbas labai priklauso nuo temperatūros pokyčių.
Tokie rodikliai kaip maksimalioji izometrinè jèga, jègos greitis ir atsipalaidavimas (Oksa and Rintamaki, 1995), taip pat galingumas (Oksa et al., 1996) sumažèja nukritus raumenų temperatūrai. K. Backx ir kt. (2000) teigè, kad pakilusios temperatūros raumenų jègos rodikliai gali pagerèti, kai yra atliekami didelio intensyvumo pratimai. Pašildžius raumeni padideja jo galingumas, dèl pagreitejjusios ATP hidrolizès spartėja raumens atsipalaidavimas, dèl pagreitèjusio $\mathrm{Ca}^{2+}$ pernešimo i sarkoplazminį tinklą padidèja raumens susitrau- 
kimo greitis, nes raumens skersiniai tilteliai po šildymo geba daugiau kartu sukibti (Ichihara, 1998). Raumeni šaldant gaunami atvirkštiniai rezultatai. Po šaldymo sumažèja raumens jèga, galingumas (Mattacola and Perrin; 1993; Oksa and Rintamaki, 1995), greitis ir susitraukimas, sulètèja medžiagu apykaita (Ferretti, 1992).

Nepavyko rasti darbu̧, nagrinėjančių temperatūros poveikị žmogaus griaučių raumenims, esant dideliam raumenu susitraukimo greičiui. Todèl mūsų tyrimo tikslas - nustatyti, kaip skirtinga temperatūra veikia kelio tiesiamuju ir lenkiamuju raumenu jėga, nuovargi bei atsigavimą, kai koja tiesiama ir lenkiama per kelio sąnari fiksuotu $450^{\circ}$ / s greičiu.

Hipotezè - spèjame, kad prieš krūvi pašildytas raumuo pavargs greičiau nei iprastinès būsenos raumuo ar pašaldytas, kai yra atliekama 50 kojos tiesimų ir lenkimų fiksuotu $450^{\circ}$ / s greičiu. Tyrimo naujumas - nustateme, kaip pasyvus šildymas ir šaldymas veikia raumenų valingu judesių atlikimo efektyvumą, raumenų nuovargi ir atsigavimą maksimalaus intensyvumo fizinio krūvio metu ir po jo.

\section{TYRIMO METODIKA}

Tiriamieji - fiziškai aktyvūs 19-23 metų vyrai ( $\mathrm{n}=10$; ūgis $-177,8 \pm 5,8 \mathrm{~cm}$; kūno masè $-78,2 \pm 6,1 \mathrm{~kg})$. Tiriamieji nesikeitè. Jie buvo supažindinti su tyrimo tikslais, metodais, procedūra ir galimais nepatogumais. Norą dalyvauti tyrime jie patvirtino raštu. Tyrimas atliktas laikantis 1975 m. Helsinkio deklaracijoje priimtu principu dèl eksperimentų su žmonėmis etikos. Tyrimo protokolas aprobuotas KMU bioetikos komisijoje (Protokolo Nr. 80 / 2004).

Kojos tiesiamųjų ir lenkiamųjų raumenų savybių testavimo metodika. Tiriamieji buvo testuojami „Biodex Medical System 3“ — žmogaus kaulų ir raumenų testavimo bei reabilitacijos aparatūra. Tiriamieji sodinami i „Biodex Medical System“ irrenginio kèdę, testuojama dominuojanti koja. Nustatoma visa kelio sąnario amplitude (ištiesus ir sulenkus koją), koja fiksuojama per kelio sąnari $90^{\circ} \mathrm{kampu}$, pasveriama tada, kai ji fiksuota $105 \pm 5^{\circ}$ kampu.

Raumenų pasyvaus šildymo metodika. Tiriamieji 45 minutes kojas laikè šiltoje vonioje, kurios vandens temperatūra $-44 \pm 1^{\circ} \mathrm{C}$. Šitaip buvo padidinta kelio tiesiamuju ir lenkiamuju raumenų temperatūra. Remiantis A. J. Sargeant
(1987) metodika, keturgalvio šlaunies raumens temperatūra $3 \mathrm{~cm}$ gylyje būna apie $38,9 \pm 0,3^{\circ} \mathrm{C}$. Tokiame raumens gylyje užregistruota temperatūra laikoma vidutine dirbančiujų raumenų temperatūra (Blomstrand et al., 1984).

Raumenų pasyvaus šaldymo metodika. Tiriamieji kojas du kartus po 15 min (darydami 10 min pertrauką) panardindavo į šaltą vonią, kurios vandens temperatūra $-15 \pm 1^{\circ} \mathrm{C}$ (Meeusen and Lievens, 1986; Ducharme et al., 1991; Eston and Peters, 1999). Remiantis R. Meeusen ir I. Lievens (1986) metodika, keturgalvio šlaunies raumens vidinè temperatūra, pašaldžius kojas tokiu būdu, sumažèja $7-10^{\circ} \mathrm{C}$.

Laktato (La) koncentracijos kraujyje nustatymo metodika. Laktato koncentracija kraujyje buvo nustatoma Eksan-G analizatoriumi (Kulis et al., 1988). Kapiliarinio kraujo mėginiai imti iš piršto prieš krūvị ir praejjus 5 bei 30 min po jo.

Kreatinkinazès (CK) aktyvumo kraujo serume nustatymo metodika. CK aktyvumui kraujo serume iqvertinti iš tiriamujų rankos venos buvo imamas kraujo mėginys (apie $5 \mathrm{ml}$ ). Mėginio analizavimo procedūra atlikta KMUK Biochemijos laboratorijoje. Standartinėmis sąlygomis sukrešèjęs kraujas 10-15 min centrifuguojamas. Biocheminè analizè atlikta naudojant automatini biochemini analizatoriu „Monarch“ (gamintojas Instrumentation Laboratory SpA, USA-Italy). CK aktyvumas kraujo serume buvo vertinamas $1 \mathrm{~h}$ prieš krūvị ir praėjus 24 h po jo (Clarkson, Sayers, 1998).

Tyrimo eiga. Iš viso atlikti trys eksperimentai - kai raumuo buvo iprastinès temperatūros, pašildytas ir pašaldytas. Tarp tyrimų buvo ne mažesnè kaip mėnesio pertrauka. Eksperimentai vienas nuo kito skyrèsi tik tuo, kad antro metu tiriamuju, atliekančių izokinetinio krūvio testą, raumenų temperatūra buvo padidinta $\sim 2,7^{\circ} \mathrm{C}$ (Saergeant, 1987), trečio — sumažinta $\sim 7-10^{\circ} \mathrm{C}$ (Meeusen and Liemens, 1986). Visų eksperimentų eiga (kai raumuo buvo iprastinès temperatūros, pašildytas ir pašaldytas) buvo ta pati. Kambario temperatūra viso tyrimo metu buvo pastovi $\left(20-22^{\circ} \mathrm{C}\right)$. Registruojant kelio tiesiamuju ir lenkiamujų raumenų rodiklius buvo atliekama: kontrolinis testavimas prieš krūvị (3 kartus tiesiant ir lenkiant koją per kelio sąnari fiksuotu $450^{\circ}$ / s greičiu); praejjus 2 min - izokinetinis krūvis (50 kojos tiesimų ir lenkimų per kelio sąnari fiksuotu $450^{\circ}$ / s greičiu); praejjus 10, $30 \mathrm{~min}, 1$ h $10 \mathrm{~min}$ ir $24 \mathrm{~h}$ po krūvio - kontrolinis testavimas pagal 
tą pati protokolą. Laktato koncentracija kraujyje buvo nustatoma prieš fizini krūvị bei praèjus 5 ir 30 min po jo. Kreatinkinazès aktyvumas kraujo serume nustatomas prieš krūvị ir praejjus $24 \mathrm{~h}$ po jo.

Statistiniai skaičiavimai. Apdorodami tyrimų duomenis, apskaičiavome aritmetini vidurki, standartini nuokrypi. Skirtumų tarp aritmetinių vidurkių reikšmingumas buvo nustatomas pagal dvipusį nepriklausomų imčių Stjudento t kriterijų. Aritmetinių vidurkių skirtumo reikšmingumo lygmuo buvo laikomas svarbiu, kai paklaida mažesnè nei 5\% ( $<0,05)$. Skaičiavome naudodamiesi statistiniais Microsoft ${ }^{\circledR}$ Excel 2003 ir SPSS paketais.

\section{REZULTATAI}

Tyrimo rezultatai parodè: kai raumuo buvo iprastinės temperatūros, pašildytas, pašaldytas ir dirbo maksimaliuoju greičiu, kelio tiesiamuju bei lenkiamujų raumenų jèga 50-o susitraukimo metu (A 0) sumažèjo (iprastinės temperatūros tiesiamujų raumenu $-18,1 \pm 14,2 \mathrm{~N} \cdot \mathrm{m}$, pašildytu $-19,9 \pm 14,3 \mathrm{~N} \cdot \mathrm{m}$, pašaldytu $-20,8 \pm 9,2$ $\mathrm{N} \cdot \mathrm{m}$; iprastinès temperatūros lenkiamujų raumenų $-9,0 \pm 7,2 \mathrm{~N} \cdot \mathrm{m}$, pašildytu $-8,3 \pm 8,9 \mathrm{~N} \cdot \mathrm{m}$, pašaldytu $-5,8 \pm 5,2 \mathrm{~N} \cdot \mathrm{m}(\mathrm{p}<0,05)$, lyginant su kontroline reikšme) (1 pav.). Praejjus $30 \mathrm{~min}$ (A 30) po krūvio reikšmingai skyrèsi pašildytų $(97,4 \pm 19,4 \mathrm{~N} \cdot \mathrm{m})$ ir pašaldytu $(79,9 \pm 36,7 \mathrm{~N} \cdot \mathrm{m})$ kelio tiesiamuju raumenu jèga $(\mathrm{p}<0,05)$ (1 A pav.). Po krūvio praéjus 10 min (A 10), reikšmingai skyrèsi pašildytu $(85,9 \pm 15,5 \mathrm{~N} \cdot \mathrm{m})$ ir pašaldytų $(64,9 \pm 22,2 \mathrm{~N} \cdot \mathrm{m})(\mathrm{p}<0,05)$ kelio lenkiamuju raumenu jèga; praèjus $1 \mathrm{~h} 10 \mathrm{~min}$ po krūvio (A 70), reikšmingas jègos skirtumas aptiktas, kai kelio lenkiamieji raumenys buvo iprastinès temperatūros $(61,9 \pm 11,9 \mathrm{~N} \cdot \mathrm{m})$ ir pašildyti $(80,1 \pm 17,1 \mathrm{~N} \cdot \mathrm{m})(\mathrm{p}<0,05)(1 \mathrm{~B}$ pav. $)$.

Tyrimo rezultatai parode, kad raumenų susitraukimo jèga esant maksimaliajam greičiui testavimo metu tiesiant koją sumažèjo $~ 80 \%$, lenkiant — 85\% (2 pav.). Kelio tiesiamujų rau-

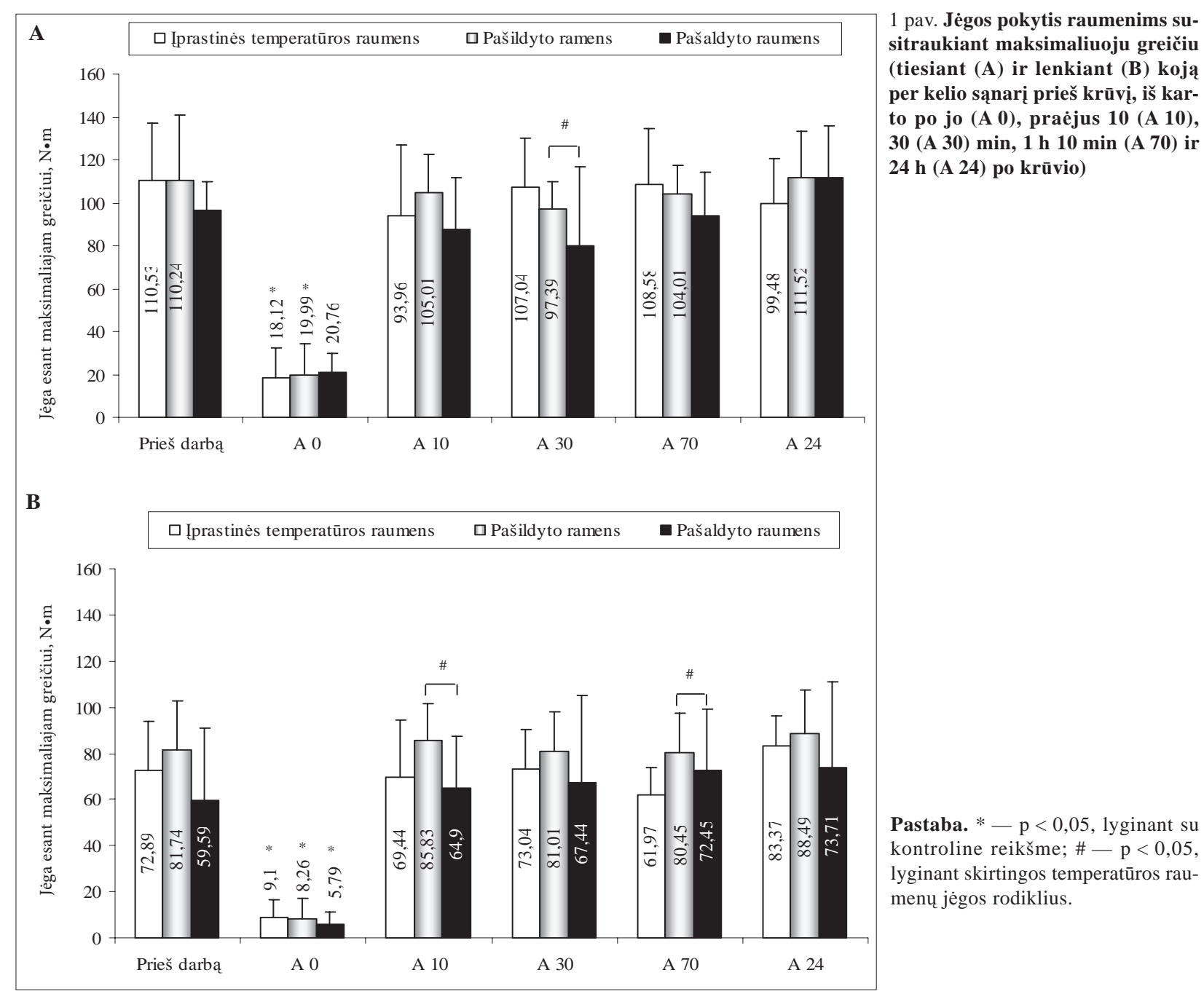


2 pav. Jègos pokytis raumenims susitraukiant maksimaliuoju greičiu, kai atliekamas izokinetinis krūvis (tiesiant (A), lenkiant (B) koją per kelio sąnari fiksuotu $450^{\circ}$ / s greičiu bei po krūvio praėjus 10 (A 10), 30 (A 30) min, 1 h $10 \mathrm{~min}$ (A 70) ir 24 h (A 24))
Pastaba. $p<0,05$ - kojos tiesiamuju ir lenkiamujų raumenų jẻgos pokytis, lyginant su kontroline reikšme, kai raumuo: $\neq$ - iprastinès temperatūros, * — pašildytas, $†$ - pašaldytas. \#- $\mathrm{p}<0,05$, iprastinès temperatūros ir pašaldytų kojos tiesiamuju ir lenkiamuju raumenų jẻgos pokyčio skirtumas.

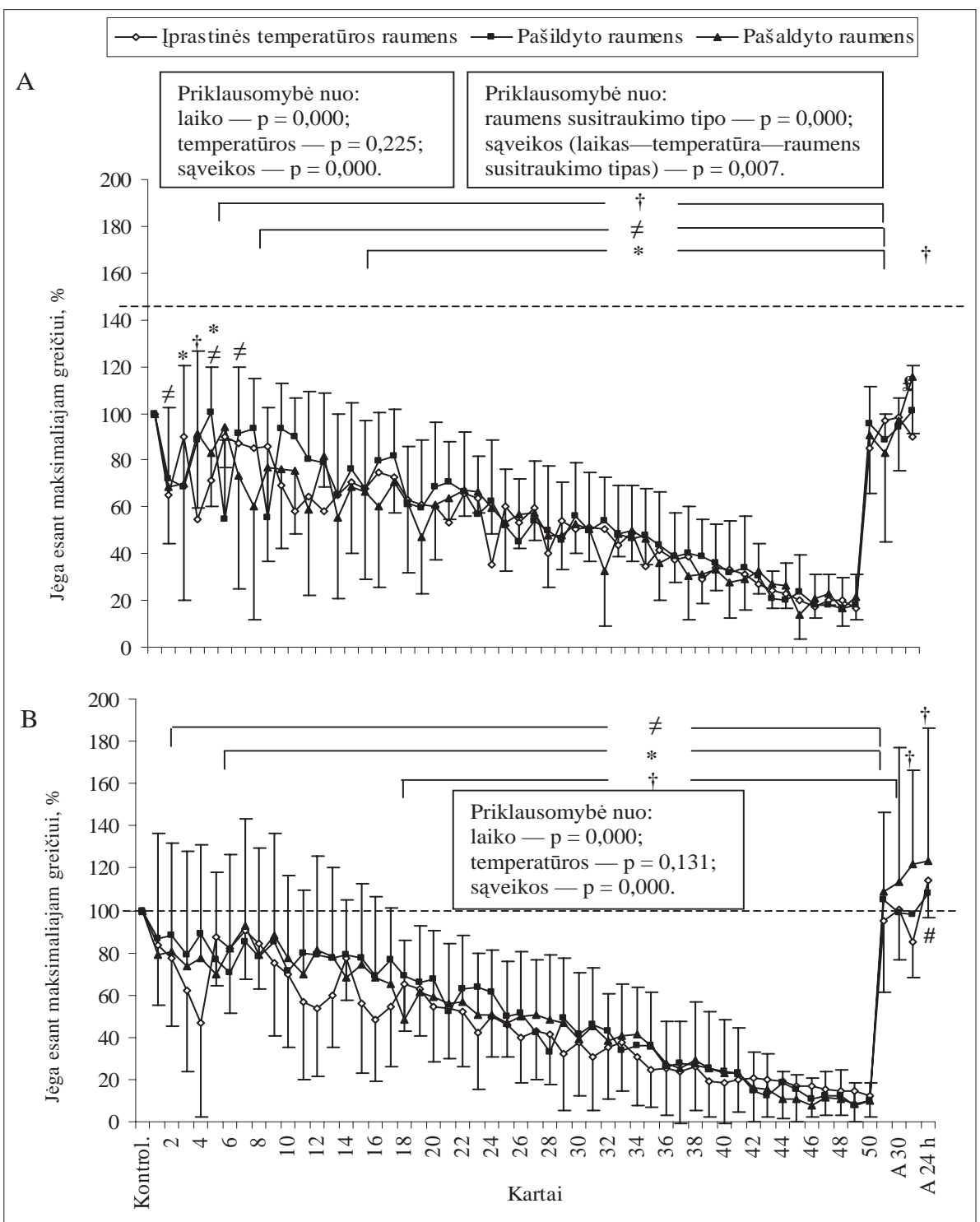

3 pav. Iprastinės temperatūros, pašildyto ir pašaldyto raumens kreatinkinazès (CK) aktyvumas kraujo serume $1 \mathrm{~h}$ prieš krūvị ir praejus 24 h (A 24) po jo

Pastaba. Matavimai atlikti prieš krūvị ir praejus 24 h po jo. ${ }^{*}-\mathrm{p}<0,05, \mathrm{CK}$ aktyvumas kraujo serume reikšmingai skiriasi nuo kontrolinès reikšmès. $\dagger-\mathrm{p}<0,05$, ịprastinès temperatūros ir pašaldyto raumens $C K$ reikšmingai skiriasi; $\neq-p<0,05$, iprastinès temperatūros ir pašildyto raumens CK aktyvumas kraujo serume reikšmingai skiriasi.

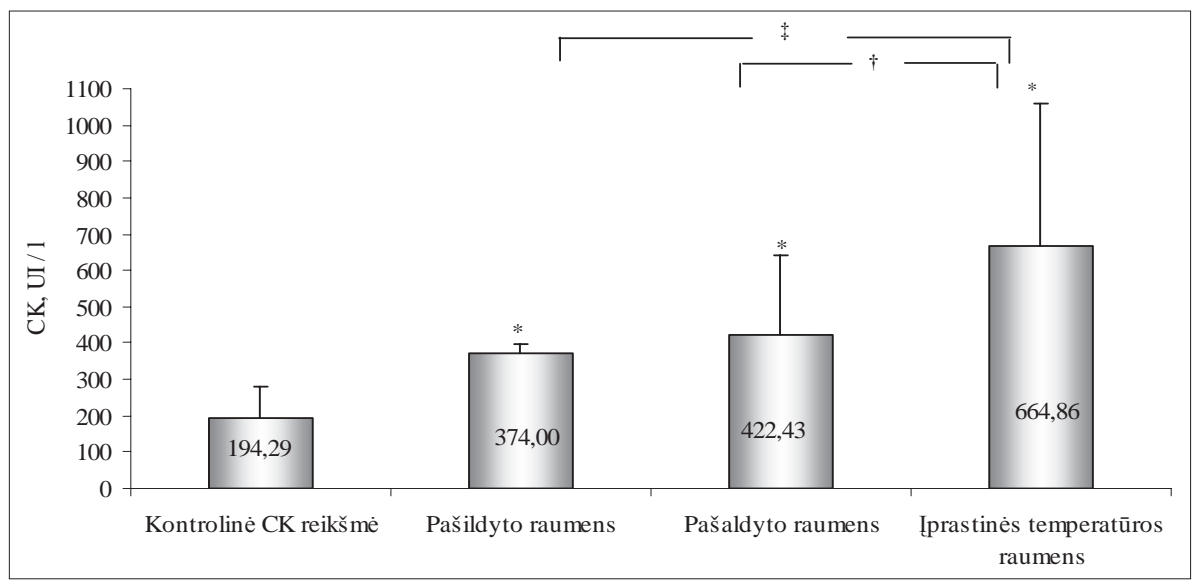

menu jëga statistiškai patikimai atsigavo praėjus 10 min po krūvio ( $<$ 0,05) (2 A pav.). Vertindami kelio lenkiamujų raumenu jègą pastebėjome reikšmingą pašildyto, pašaldyto ir iprastinès temperatūros raumens jègos $(\mathrm{p}<0,05)$ sumažè- jimą, lyginant su kontroline reikšme (2 B pav.). Kai raumuo susitraukinejja maksimaliai valingai, dinaminio susitraukimo jèga tiesiant ir lenkiant koją per kelio sąnari fiksuotu $450^{\circ}$ / s greičiu priklauso nuo laiko $(p=0,001)$ ir nuo raumens 


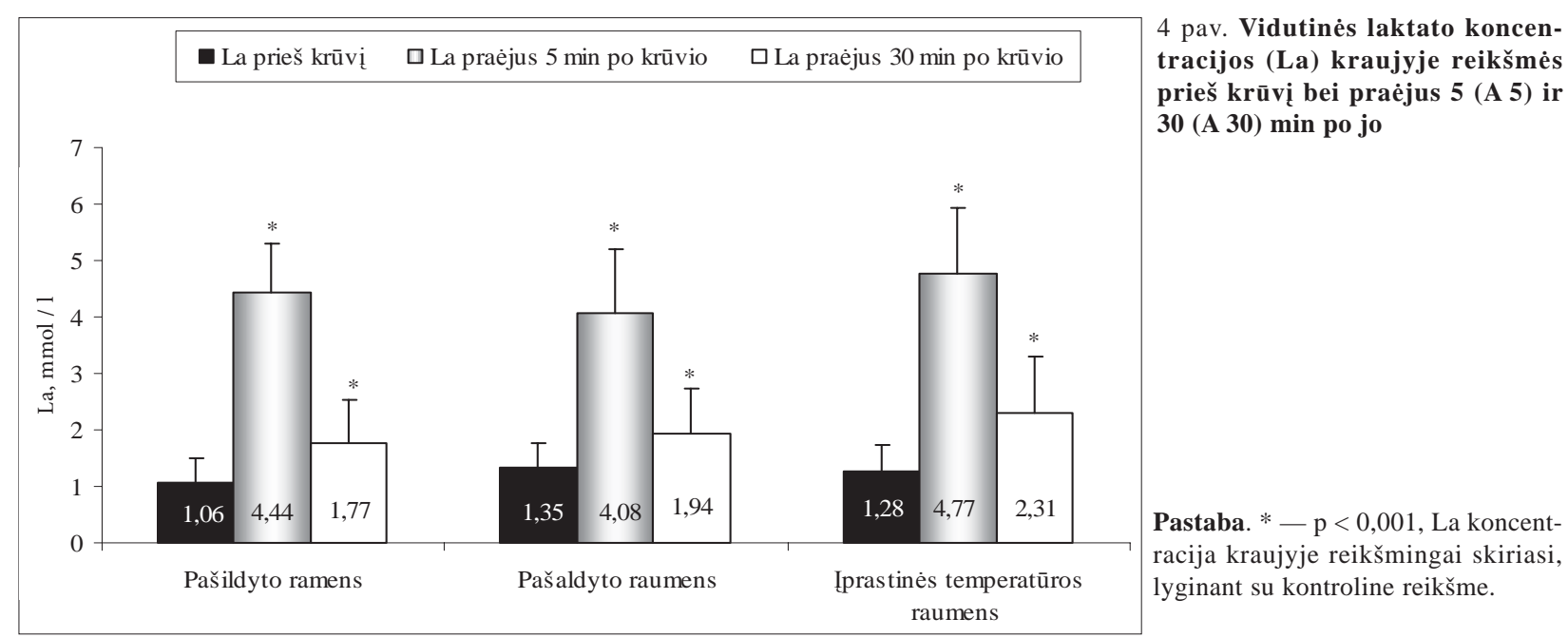

(agonistas-antagonistas) $(\mathrm{p}=0,001)$. Nustatytas laiko, raumens temperatūros $(\mathrm{p}=0,001)$ ir laiko, raumens temperatūros ir raumens (agonistasantagonistas $)(p=0,007)$ sąveikos reikšmingas skirtumas.

Kreatinkinazès (CK) aktyvumas kraujo serume, praejjus 24 h (A 24) po izokinetinio krūvio, reikšmingai padidejjo, palyginti su kontroline reikšme $(\mathrm{p}<0,05)$, kai raumuo buvo iprastinès temperatūros, pašildytas ir pašaldytas. Lygindami iprastinès temperatūros ir pašaldytų raumenų CK aktyvumo kraujo serume reikšmes praejus 24 h po krūvio, aptikome statistiškai reikšmingą skirtumą $(\mathrm{p}<0,05)$ (3 pav.). Praejjus 5 min po krūvio (A 5), laktato koncentracija kraujyje reikšmingai padidèjo, palyginti su kontroline reikšme $(\mathrm{p}<0,05)$ ir išliko padidejjusi praejjus 30 min po krūvio, kai raumuo buvo iprastinès temperatūros, pašildytas ir pašaldytas $(\mathrm{p}<0,05)(4 \mathrm{pav}$.$) .$

\section{REZULTATŲ APTARIMAS}

Pagrindiniai tyrimo duomenys parodè, kad šildymas ir šaldymas reikšmingai nepakeitė maksimaliuoju greičiu dirbančių kelio tiesiamuju ir lenkiamujų raumenų susitraukimo jëgos. Raumenu atsparumas nuovargiui 50 kartu tiesiant ir lenkiant koją per kelio sąnarị nepriklauso nuo šildymo ir šaldymo. Raumenų susitraukimo jèga esant fiksuotam $450^{\circ}$ / s greičiui nepriklausomai nuo temperatūros atsigavo praejjus 10 min po krūvio. Šildymas ir šaldymas prieš krūvị netiesiogiai sumažino raumens pažeidos simptomus - CK aktyvumą kraujo serume po krūvio praejjus $24 \mathrm{~h}$. La koncentracija kraujyje po krūvio nepriklausė nuo temperatūros.
Kodėl raumens susitraukimo jẻga nepriklauso nuo temperatūros? Atlikto tyrimo duomenys sutampa su K. Backx ir kt. (2000) pateiktaisiais: pašildyto raumens rodikliai tiriamajam bègant tris trumpuosius nuotolius po $30 \mathrm{~m}$ nepagerejjo; praejus 60 min po krūvio (atsigavimo metu) eksperimentas buvo pakartotas pagal tą pati protokolą, tačiau geresni rezultatai gauti tada, kai raumuo nebuvo šildomas. A. J. Sargeant (1987) nustatè, kad temperatūros pakeitimas didina raumenų jègą (minant veloergometra, jèga ir galingumas padidèdavo $4 \%$, kai raumens temperatūra būdavo padidinama $1^{\circ} \mathrm{C}$ ). Taip pat šis mokslininkas irodė kad, maksimalioji jẻga reikšmingai sumažèja šaldant raumenị dviejų dydžių temperatūromis (18 ir $\left.12^{\circ} \mathrm{C}\right)$, lyginant su iprastinès raumens temperatūros $\left(32^{\circ} \mathrm{C}\right)$ rodikliais, kai krūvis atliekamas veloergometru izokinetiniu režimu. L. Nybo ir B. Nielsen (2001) nustate šildomo raumens jẻgos sumažèjimą atliekant didelio intensyvumo pratimus. Jie aiškina, kad jèga sumažèja dèl hipertermijos ir centrinès nervų sistemos nuovargio. D. Bishop ir kt. (2003) nustatè, kad raumenų temperatūros padidinimas, skirtingai negu šaldymas, teigiamai veikia raumenų elastinguma, deguonies atsiskyrimą nuo hemoglobino ir mioglobino, pagerina kraujo tèkmę raumenyse, pagreitina metabolines reakcijas, padidina veikimo potencialo sklidimo sarkolema greiti (Shellock, Prentice, 1985), miozino ir kalcio ATP-aziu aktyvumą (Ichihara, 1998). C. G. Matacola ir D. H. Perin (1993) atliko pado lenkiamujuc raumenų izokinetini testą ir irodè reikšmingą jègos padidejjimą raumenis pašaldžius $15^{\circ} \mathrm{C}$ temperatūra. D. Ball ir kt. (1999) po raumenų pašildymo taikè ciklini bėgimą ir nustatè, kad jèga gali padidèti iki 15\%. Mūsų tyrimo rezultatai rodo, kad šildymas 
ir šaldymas reikšmingai nepakeitè maksimaliuoju greičiu dirbančių kelio tiesiamujų ir lenkiamuju raumenų susitraukimo jejgos.

Kodèl raumenų nuovargis nepriklauso nuo temperatūros? Ilgalaikè raumenų aktyvacija neišvengiamai sukelia raumenų nuovargi. Raumenu nuovargis apibūdinamas kaip negebėjimas išlaikyti reikiamo krūvio intensyvumo (Wessley, Thomas, 1990). Raumenų nuovargio pobūdis priklauso nuo raumens darbo arba aktyvacijos tipo. Yra žinoma, kad ištvermè gali pablogèti esant aukštai aplinkos temperatūrai ir priklauso nuo kūno pradinès temperatūros krūvio metu (Febbraio et al., 1994). Atlikto tyrimo rezultatai rodo, kad raumenų atsparumas nuovargiui 50 kartų tiesiant ir lenkiant koją per kelio sąnarį nepriklauso nuo šildymo ir šaldymo. E. M. Haymes ir R. A. Rider (1983) palygino pašaldytų ir iprastinès temperatūros kelio tiesiamujų raumenų nuovargi ir nustatė nereikšmingą jègos sumažèjimą atliekant kelio tiesimo judesius. J. Gonzalez-Alonso ir kt. (1990) teigè, kad šildymas gali sumažinti organizmo pajègumą atlikti ištvermès, ilgos trukmès ar didelio intensyvumo pratimus (Morris et al., 2000). Gana sudètinga paaiškinti, koks yra raumenų šildymo arba šaldymo poveikio mechanizmas, ar jis veikia raumenų atsigavimo kaitą. Manome, kad raumens funkcijos atsigavimas po dinaminio krūvio (50 kojos tiesimų ir lenkimų per kelio sąnari fiksuotu $450^{\circ} / \mathrm{s}$ greičiu) yra susijęs su metaboliniu nuovargiu. Nustatyta, kad praejjus 2-3 min po dinaminio krūvio raumenyse normalizuojasi kreatinfosfato koncentracija, o po 10-15 min vandenilio jonų koncentracija (Inbar et al., 1996). Manoma, kad raumeninès skaidulos mioplazmoje padaugèja $\mathrm{Ca}^{2+}$, kurie vèliau lemia nuovargio atsiradimą (Westerblad et al., 1993). Atlikto tyrimo duomenys parodè, kad raumenu susitraukimo jèga esant fiksuotam $450^{\circ}$ / s greičiui nepriklausomai nuo temperatūros atsigavo po krūvio praėjus 10 min.

Kodėl La koncentracija kraujyje nepriklauso nuo temperatūros, o CK aktyvumas kraujo serume po 24 valandų reikšmingai skiriasi? Atliekant intensyvų kartotini ekscentrinį-koncentrinį fizinị krūvị, atsiranda struktūrinis nuovargis, kuris gali paveikti raumenis ivairiai: pažeisti raumenines skaidulas ar net sukelti raumenų pertempima, plyšimą (Enoka, 1996). Vidinè ląstelių pažeida sukelia uždegiminius procesus ir skausma, kuris atsiranda praejjus 24-72 valandoms po fizinio krūvio ir atslūgsta po 5-7 dienų (Cleak and Eston, 1992). Izokinetinio (ekscentrinio-koncentrinio) susitraukimo metu aktyvus raumuo dèl krūvio yra ištempiamas daugiau, negu jis pats gali pailgèti. Dèl tempimo pratimu per mechaniškai valdomus $\mathrm{Ca}^{2+}$ kanalus arba įtrūkus sarkoplazminiam tinklui, T vamzdeliams ar sarkolemai i sarkoplazmą patenka didesnès koncentracijos $\mathrm{Ca}^{2+}$ ir sukelia filamentų, palaikančių selektyvią sarkomero struktūrą, hidrolizę arba irimą (Friden, Lieber, 1992). Sumažinus raumenų temperatūrą, sulètėja nervo laidumo greitis ir raumens verpstės aktyvumas. Viduląstelinę raumenų pažeidą nusako plazmos kreatinkinazès, mioglobino ir baltymų metabolitų padidèjimas juose: per mikroskopą matomi raumeninès skaidulos tarpląsteliniai struktūriniai pokyčiai - suyra miofibrilès, raumeninès skaidulos sarkolema, sarkoplazminis tinklas (Friden, Lieber, 1992). Atlikto tyrimo duomenys sutampa su R. Eston ir D. Peters (1999), S. Sipavičienès ir kt. (2003) gautaisiais — raumenų šaldymas, naudojant šalto vandens vonią pažeistiems raumenims, sumažina kreatinkinazės aktyvumą kraujo serume po krūvio praejjus 24 h. Tai paaiškinama: po lokalaus raumenu šaldymo sumažèjus limfos ir kraujo kapiliarų pralaidumui, mažiau kreatinkinazès patenka į raumens limfinę sistemą (Eston and Peters, 1999; Sipavičienè ir kt., 2003).

\section{IŠVADOS}

1. Temperatūros pokytis reikšmingai nepakeitė maksimaliuoju greičiu dirbančių kelio tiesiamujų ir lenkiamujų raumenų susitraukimo jègos. Raumenų atsparumas nuovargiui 50 kartų tiesiant ir lenkiant koją per kelio sąnarį nepriklauso nuo šildymo ir šaldymo. Raumenų susitraukimo jèga esant $450^{\circ} / \mathrm{s}$ greičiui atsigavo praèjus 10 min po krūvio nepriklausomai nuo temperatūros.

2. Tiek šildymas, tiek šaldymas prieš krūvị netiesiogiai sumažino raumenų pažeidos simptomus - CK kieki praejjus 24 h po krūvio. Skirtinga temperatūra po krūvio reikšmingai nepaveikė laktato koncentracijos kraujyje kaitos. 


\section{LITERATŪRA}

Backx, K., McNaughton, L., Palmer, G., Carlisle, A. (2000). Effect of differing heat and humidity on the performance and recovery from multiple high intensity, intermittent exercise bouts. International Journal of Sports Medicine, 21, 400-405.

Ball, D., Burrows, C., Sargeant, A. J. (1999). Human power output during repeated sprint cycle exercise: The influence of thermal stress. European Journal of Applied Physiology, 79, 360-366.

Bennett, A. H. (1990). Thermal dependence of locomotors capacity. American Journal of Physiology, 259, R 253-258.

Bishop, D., Bonetti, D., Spencer, M. (2003). The effect of an intermittent, high-intensity warm-up on supramaximal kayak ergometer performance. Journal of Sports Science, 21 (1), 13-20.

Blomstrand, E., Bergh, U., Essen-Gustavsson, B. and Eklomb, B. (1984). Influence of low muscle temperature in human skeletal muscles. Acta Physiologica Scandinavica, 107, 33-37.

Clarkson, P. A., Sayers, S. P. (1998). Exercise-induced muscle damage in humans. In H. Nose, E. R. Hadel and K. Morimoto (Eds.), Nagano Symposium on Sport Science (pp. 545-563). Carmel, IN: Cooper Publishing Group.

Cleak, M. J. and Eston, R. G. (1992). Muscle soreness, swelling, stiffness and strenght loss after intense eccentric exercise. British Journal of Sports Medicine, 26, 267-272.

Ducharme, M. B., Van Helder, W. P., Radomski, M. W. (1991). Cyclic intramuscularly temperature fluctuations in the human forearm during cold-water immersion. Journal of Applied Physiology, 63 (3-4), 193-198.

Enoka, R. M. (1996). Excentric contractions require unique activation strategies by the nervous system. Journal of Applied Physiology, 81, 2339-2346.

Enoka, R. M. (1994). Neuromechanical basis of kinesiology. Champaign, IL: Human Kinetics. P. 273-283.

Eston, R. and Peters, D. (1999). Effect of cold water immersion on the symptoms of exercise-induced muscle damage. Journal of Sport Science, 17, 231-238.

Febbraio, M. A., Snow, R. J., Hargeaves, M. et al. (1994). Muscle metabolism during exercise and the heat stress in trained men: Effect of acclimation. Journal of Applied Physiology, 76, 589-597.

Ferretti, G. (1992). Cold and muscle performance. International Journal of Sports Medicine, 13, S $185-187$.

Friden, J., Lieber, R. L. (1992). Structural and mechanical basis of exercise-induced muscle injury. Medicine Science of Sports Exercise, 24, 521-530.

Gonzalez-Alonso, J., Teller, C., Andersen, S. L. et al. (1999). Influence of body temperature on the development of fatigue during prolonged exercise in the heat. Journal of Applied Physiology, 86, 1032-1039.

Haymes, E. M. and Rider, R. A. (1983). Effect of leg cooling on peak isokinetic torque and endurance. American Correct Therapy Journal, 37, 109-115.

Ichihara, Y. (1998). Effect of temperature on Ca induced Ca release (CICR) rate. Masui, 47 (3), 281-285.

Inbar, O., Bar-Or, O., Skinner, J. S. (1996). The Wingate
Anaerobic Test (pp. 345-250). Human Kinetics.

Kulis, Y. U., Laurinavichyus, A., Firantas, S. G., Kurtinaitene, B. S. (1988). Determination of lactic acid in blood with an exan-G analyzer. Journal of Analytical Chemistry, 43 (7), 1521-1523.

Mattacola, C. G. and Perrin, D. H. (1993). Effect of cold water application on isokinetic strength of the plantar flexors. Isokinetic Exercise Science, 3, 152-154.

Meeusen, R. and Lievens, I. (1986). The use of cry therapy in sport injuries. Sports Medicine, 3, 398-414.

Morris, J. G., Nevill, M. E., Williams, C. (2000). Physiological and metabolic responses of female games and endurance athletes to prolonged, intermittent, highintensity running at $30^{\circ}$ and $16^{\circ} \mathrm{C}$ ambient temperature. European Journal of Applied Physiology, 81, 84-92.

Nybo, L., Nielsen, B. (2001). Hyperthermia and central fatique during prolonged exercise in humans. Journal of Applied Physiology, 91, 1055-1060.

Oksa, J. and Rintamaki, H. (1995). Dynamic work in cold. Arctic Medicine, 54, 29-31.

Oksa, J., Rintamaki, H., Makinen, T., Martikala, V. and Rusko, H. (1996). EMG-activity and muscular performance of lower leg during stretch-shortening cycle after cooling. Acta Physiologica Scandinavica, 157, 71-78.

De Ruiter, C. J., De Haan, A. (2000). Temperature effect on the force-velocity relationship of the fresh and fatiqued human adductor pollicis muscle. Pflügers Archiv: European Journal of Physiology, 440, 163-170.

Sargeant, A. J. (1987). Effect of muscle on leg extension force and short-term power output in humans. European Journal of Applied Physiology, 56, 693-698.

Shellock, F. G., Prentice, W. E. (1985). Warming-up and stretching for improved physical performance and prevention of sports-related injuries. Sports Medicine, 2, 267-278.

Sipavičienė, S., Skurvydas, A., Mickevičienè, D., Špokas, M., Masiulis, N. (2003). Šaldymo poveikis raumens atsigavimo dinamikai po ekscentrinio-koncentrinio fizinio krūvio. Ugdymas. Kūno kultūra. Sportas, 3 (50), 64-70.

Wessely, S., Thomas, P. K. (1990). The chronic fatigue syndrome (myalgic encephalomyelitis or post viral fatigue). In C. Kennard (Ed.), Recent Advances in Neurology (Vol. 6, pp. 85-132). Edinburg: Churchill Livingstone.

Westerblad, H., Duty, S., Allen, D. G. (1993). Intracellular calcium concentration during low-frequency fatigue in isolated single fibres of mouse skeletal muscle. Journal of Applied Physiology, 75, 382-388. 


\title{
THE EFFECT OF DIFFERENT TEMPERATURE ON KNEE FLEXORS AND EXTENSORS DURING FATIGUING EXERCISE AND RECOVERY
}

\author{
Irina Ramanauskiené ${ }^{1,2}$, Marius Brazaitis ${ }^{1}$, Albertas Skurvydas ${ }^{1}$, Vitas Linonis ${ }^{2}$, \\ Aleksas Stanislovaitis ${ }^{1}$, Mindaugas Dubosas ${ }^{1,2}$ \\ Lithuanian Academy of Physical Education ${ }^{1}$, Kaunas University of Technology ${ }^{2}$, \\ Kaunas, Lithuania
}

\begin{abstract}
The aim of the present study was to establish the influence of muscle heating and cooling on kneeflexors and extensors, during fatiguing exercise and recovery. The participants of the study were 10 healthy male, age: $19-23$ years; height $-177.8 \pm 5.8$; weight $-78.2 \pm 6.1$, with no history of knee ligament. The study was performed in the human motoric laboratory of Lithuanian Academy of Physical Education in year 2005 / 2006. All the subjects have done non-stop 50 repetitions of knee flexion and extension at $450^{\circ}$ / s range motion on "Biodex System Pro 3" device (first experiment) and the same isokinetic exercise was repeated after the quadriceps muscle had been heated (second experiment) and had been cooled (third experiment). Before (pre-exercise), ten minutes (post-exercise), $30 \mathrm{~min}, 1$ hours $10 \mathrm{~min}$ and 24 hours after the fatiguing exercise, three knee extensions / flexions with angular velocity of $450^{\circ}$ / s were performed. A blood lactate sample was taken before initial measurements and following exercise at 5 and 30 minutes. The increase of CK and muscle pain 24 hours after the fatiguing exercise.

After individual analysis of values, it was found, that muscle heating or cooling before the exercise had no effect on muscle recovery time. Power in max speed was declined (A 0): knee extension normal muscle temperature $-18.1 \pm 14.2 \mathrm{~N} \cdot \mathrm{m}$, heating muscle temperature $-19.9 \pm 14.3 \mathrm{~N} \cdot \mathrm{m}$, cooling muscle $20.8 \pm 9.2 \mathrm{~N} \cdot \mathrm{m}$; knee flexion normal muscle temperature $-9.0 \pm 7.2 \mathrm{~N} \cdot \mathrm{m}$, heating muscle temperature $8.3 \pm 9.0 \mathrm{~N} \cdot \mathrm{m}$, cooling muscle $-5.8 \pm 5.2 \mathrm{~N} \cdot \mathrm{m}(\mathrm{p}<0.05)$. Power in max speed declined: knee extension $\sim 80 \%$, flexion 85\%.

The evidence obtained in this study showed that, muscle heating or cooling before exercise didn't decrease power in max speed of knee extensors and flexors. Muscle heating or cooling before the exercise had no effect on muscle recovery time, however increased a post-exercise blood lactate value. After 24 hours the CK in muscles was increased.
\end{abstract}

Keywords: isokinetic exercise, power in max speed, muscle fatigue, recovery, heating and cooling.

Gauta 2006 m. sausio 12 d.

Received on January 12, 2006

Priimta 2006 m. gegužès 25 d.

Accepted on May 25, 2006
Irina Ramanauskienè

Lietuvos kūno kultūros akademija

(Lithuanian Academy of Physical Education)

Sporto g. 6, Lt-44221 Kaunas

Lietuva (Lithuania)

E-mail Irina.Ramanauskiene@ktu.lt 